выявлены более высокие риски общей и сердечно-сосудистой смертности, риск развития ОНМК и риск смерти от ОНМК, а также риск развития ИМ по сравнению со стартовым лечением метформином. На гликлазиде, глибенкламиде и глимепириде относительный риск (ОР) ОНМК был больше по сравнению с метформином, однако ОР фатального ОНМК достоверно выше только на глибенкламиде и на глимепириде. На гликлазиде по сравнению с глибенкламидом было отмечено достоверное снижение риска фатальнго ОНМК.

Ключевые слова: сахарный диабет 2-го типа, лечение, риск общей и сердечно-сосудистой смертности

\title{
RISK OF TOTAL AND CARDIOVASCULAR MORTALITY, MAJOR CARDIOVASCULAR EVENTS IN PATIENTS WITH TYPE 2 DIABETES MELLITUS, DEPENDING ON THERAPY CHOICE UPON MAKING A DIAGNOSIS
}

\section{V.I. Pan'kiv, L.A. Khutorska}

Abstract. The purpose of this research is studying the risk of the total and cardiovascular mortality rate as well as the risk of the development of myocardial infarction (MI) and acute disturbances of the cerebral circulation (ADCC) in patients with type 2 diabetes mellitus (DM), depending on the choice of a peroral sugar-reducting agent (PSRA) after making a diagnosis. A retrospective cohort study was undertaken on the basis of operative lists of type 2 DM patients, being on a dispensary registration at medical treatment - preventive facilities of the Transcarpathian region. The patients with type 2 DM were subdivided into cohorts, depending on the type of obtained therapy: with metformin, glyclazide, glibenclamide and glimepiride. Higher risks of the total and cardiovascular mortality rate, the risk of the development of ADCC and the risk of death from ADCC as well as the risk of the development of MI as compared to the starting metformin treatment were detected in patients with type $2 \mathrm{DM}$ who received sulfonylurea drugs as staring therapy in 5 years after establishing the diagnosis. A relative risk (RR) of ADCC was higher with glyclazide, glibenclamide and glimepiride compared with metformin, however, a RR of fatal ADCC is considerably higher only with glibenclamide and with glimepiride. A reliable decrease of the risk of fatal ADCC was marked with glyclazide compared to glibenclamide.

Key words: type 2 diabetes mellitus, treatment, risk of total and cardiovascular mortality rate.

Ukrainian Scientific-Practical Centre of Endocrine Surgery, Transplantation of Endocrine Organs and Tissues of Ukraine's MHP (Kyiv)

\section{ВПЛИВ ВІНБОРОНУ НА ЕЛЕКТРИЧНУ СТАБІЛЬНІСТЬ ТА ЕЛЕКТРОЛІТНИЙ БАЛАНС МІОКАРДА ПРИ АЛКОГОЛЬНІЙ КАРДІОМІОПАТІЇ У ЩУРІВ}

\author{
Вінницький національний медичний університет ім. M.I. Пирогова
}

Резюме. У дослідах на щурах з експериментальною алкогольною кардіоміопатією встановлено, що вінборон (5 мг/кг в/м) так само, як і мілдронат (50 мг/кг в/м) та тіотріазолін (100 мг/кг), володіє кардіопротекторною дією. Це проявляється нормалізацією порогу фіб-

Вступ. Ще в 1975 р. у своїй резолюції Всесвітня асамблея охорони здоров'я звернула особливу увагу на серйозність проблеми зловживання алкоголем. У першу чергу, мова йде про збільшення поширеності пияцтва та алкоголізму серед населення багатьох країн світу i, особливо, в Європі [12]. На жаль, Україна належить до європейських країн не тільки за географічним розташуванням, а й за кількістю вживаного алкоголю. За статистикою, на кожного жителя України, у тому числі немовлят, вагітних і осіб літнього віку, доводиться близько 25 мл чистого алкоголю щодня. Якщо (c) О.С. Пашинська, 2013 риляції шлуночків та вмісту іонів $\mathrm{K}^{+}, \mathrm{Na}^{+}$i $\mathrm{Mg}^{2+}$ у сироватці крові. За величиною даного ефекту вінборон не поступається препаратам порівняння.

Ключові слова: вінборон, алкогольна кардіоміопатія, мілдронат, тіотріазолін.

виключити дітей і частину населення, що не вживає алкоголю, то цей показник збільшується вдвічі і сумарне споживання абсолютного алкоголю в Україні сягає 11-12 літрів на душу населення в рік (і це без обліку вживання сурогатів) [8].

Одним із тяжких ускладнень вживання алкоголю $\epsilon$ розвиток алкогольної кардіоміопатії (АКМП). Відповідно до визначення ВООЗ, АКМП - захворювання міокарда, яке асоціюється 3 порушенням функції серця і зумовлено надмірним прийомом алкоголю. Алкогольна кардіоміопатія відноситься до різновиду дилатаційної кар- 
діоміопатії, яка, за МКХ-10, виділена в окрему нозологічну форму. За даними Державного комітету статистики України, у нашій країні тільки за перше півріччя 2007 р. смертність від АКМП склала 183 на 100000 населення. При цьому аналогічні показники смертності за той же період часу від дорожньо-транспортних пригод і в результаті інфікування ВІЛ склали 201 і 94 випадки на 100000 населення відповідно [4].

Основою патогенезу АКМП є тривалий вплив алкоголю і його надзвичайно токсичного метаболіту ацетальдегіду на міокард [13]. В основі механізмів розвитку алкогольного ураження серця лежать: негативний вплив на метаболізм і енергозабезпечення клітини; пряма токсична дія на синтез білка; вплив на цитоскелет клітин; зміна процесів збудження і проведення в серцевому м'язі; зрив сполучення між збудженням і скороченням; порушення ліпідного обміну; вільнорадикальне пошкодження; іонний і гормональний дисбаланс (у першу чергу катехоламінів); токсична дія, зумовлена домішками важких металів, які використовувалися при виробництві спиртних напоїв (наприклад, кобальту); порушення мікроциркуляції.

У клінічних та експериментальних дослідах доведено, що алкогольна інтоксикація призводить до змін електрофізіологічних властивостей міокарда. Це сприяє виникненню порушень серцевого ритму аж до фібриляцій, що може стати причиною раптової смерті. За даними [7], причиною раптової серцевої смерті людей молодого та середнього віку в $30 \%$ випадків є алкогольна кардіоміопатія.

Терапія АКМП включає наступні напрямки: 1) припинення прийому алкоголю; 2) профілактика і лікування серцевої недостатності; 3) корекція метаболічних порушень, викликаних алкогольною КМП. Аналіз даних літератури свідчить, що лікування серцевої недостатності при АКМП мало відрізняється від лікування іiі іншої етіології. Принципи такої терапії детально розглянуті в чисельних рекомендаціях та відповідних посібниках $[2,6,10]$. Як засоби метаболічної терапії при різних видах кардіоміопатій використовують мілдронат та тіотріазолін $[1,9,11]$. Однак, як вважають більшість авторів, питання адекватної корекції порушень метаболізму, у тому числі і енергетичного, які супроводжують АКМП, залишається до кінця не з'ясованим. Нашу увагу привернув вітчизняний оригінальний препарат вінборон, широкий спектр фармакологічних властивостей якого вписуються в патогенез АКМП [3].

Мета дослідження. Вивчити вплив вінборону, порівняно 3 мілдронатом та тіатріазоліном на електричну стабільність міокарда та електролітний баланс у сироватці крові щурів з експериментальною алкогольною кардіоміопатією для оцінки його кардіопротекторних властивостей.

Матеріал і методи. Досліди проведені на 140 нелінійних щурах-самцях масою 180-230 г. Щури утримувались у стандартних умовах віварію ВНМУ при вільному доступі до води та їжі. Експериментальне токсичне алкогольне ураження серця моделю- вали внутрішньошлунковим уведенням щурам 50 \% етанолу (6 г/кг) протягом дев'яти тижнів [10]. Експерименти проведені 3 дотриманням Свропейської конвенції по захисту хребетних тварин, яких використовують в експериментальних та інших наукових цілях (Страсбург, 1986).

Тварин розподілили на п'ять груп: 1-ша група - інтактні; 2-га група тварини з АКМП без лікування; 3-тя, 4-та та 5-та групи - тварини 3 АКМП, ліковані вінбороном, мілдронатом та тіотріазоліном відповідно. Лікування експериментальної АКМП проводили окремо вінбороном (5 мг/кг/добу, в/м), мілдронатом (50 мг/кг/добу, в/м) та тіотріазоліном (100 мг/кг/добу в/о) у два прийоми впродовж двох тижнів, починаючи 3 2-го дня після моделювання патологічного стану. Всі препарати досліджувались у терапевтично ефективних дозах, запозичених із літератури.

Електричну стабільність міокарда оцінювали за величиною порогу фібриляції шлуночків (ПФШ), яку викликали в наркотизованих тіопенталом натрію (80 мг/кг в/о) тварин прямокутним електричним імпульсом від електростимулятора ЕC-50-1 тривалістю 10 мс, який наносили в уразливий період ЕКГ (2-ге стандартне відведення). Визначення ПФШ починали 3 амплітуди стимулювального імпульсу 0,5 мА, яку збільшували на 0,5 мА до появи стійкої фібриляції шлуночків.

Концентрацію іонів калію і натрію в сироватці крові визначали за допомогою уніфікованого методу фотометрії полум'я на фотометрі ПАЖ 3 , а кількість магнію визначали за допомогою набору реактивів фірми «Лахема».

Статистичну обробку цифрових даних проводили методом варіаційної статистики с використанням t-критерія Стьюдента при р $<0,05$.

Результати дослідження та їх обговорення. Проведені досліди показали, що уведення щурам 50 \% етанолу в дозі 6 г/кг протягом дев'яти тижнів призводить до статистично значимого зниження ПФШ у середньому на 54,5 \% відносно інтактних тварин. У подальшому, після припинення уведення етанолу, у нелікованих тварин мало місце деяке вирівнювання вказаних показників, хоча вони i наприкінці експерименту статистично значимо відрізнялися від аналогічних показників інтактних щурів (рис. 1). Терапія АКМП вінбороном, так само як і мілдронатом та тіотріазоліном, сприяла більш швидкому відновленню ПФШ. Це було помітно вже через сім днів лікування. Так, в указаний період експерименту, на тлі вінборону, мілдронату та тіотріазоліну показник рівня ПФШ виріс порівняно $з$ нелікованими тваринами на $69 \%$, $61 \%$ та $70 \%$ у середньому відповідно $(\mathrm{p}<0,05)$, залишаючись при цьому нижче рівня інтактних щурів. На 14-у добу експерименту ПФШ на тлі вінборону, мілдронату та тіотріазоліну статистично значимо перевищував величину даного показника не тільки тварин без лікування, але й інтактних щурів. Слід зауважити, що за ефективністю вінборон дещо переважав препарат порівняння мілдронат та зіставлявся з тіотріазоліном. 
Порушення електричної стабільності міокарда на тлі моделювання алкогольної кардіоміопатії супроводжувалися суттєвим іонним дисбалансом: вміст $\mathrm{K}^{+}$i $\mathrm{Mg}^{2+}$ у нелікованих тварин з АКМП знизився на $30 \%$, а концентрація $\mathrm{Na}^{+}-$навпаки, підвищилася на $18 \%$ у середньому відносно аналогічних показників у інтактних щурів (рис. 2).

Застосування препарату вінборон у тварин 3 АКМП зумовило позитивну динаміку електролітного балансу, що відмічалось уже через сім днів лікування. При цьому вінборон практично не поступався препаратам порівняння. Наприкінці курсової терапії вінбороном, мілдронатом та тіотріазоліном вміст $\mathrm{K}^{+}$i $\mathrm{Na}^{+}$у сироватці крові щурів $з$ експериментальною АКМП практично не відрізнявся від аналогічних показників інтактних тварин, тоді як у групі нелікованих тварин ці по- казники все ще статистично значимо відрізнялися від інтактних щурів. Відновлення порушеного вмісту іонів $\mathrm{Mg}^{2+}$ у крові тварин з АКМП на тлі терапії мілдронатом та тіотріазоліном порівняно з вінбороном проявило аналогічну тенденцію.

Аналізуючи отримані дані, можна відмітити, що експериментальна АКМП у щурів характеризується значним порушенням електричної стабільності міокарда, що проявляється зниженням порогу фібриляції. Однією з причин цього стану може бути іонний дисбаланс, на що вказує виявлене нами порушення концентрації іонів $\mathrm{K}^{+}, \mathrm{Na}^{+}$, $\mathrm{Mg}^{2+}$, у сироватці крові тварин з АКМП. Наше припущення збігається з точкою зору інших дослідників про значення електролітного дисбалансу у формуванні електричної нестабільності міокарда [5].

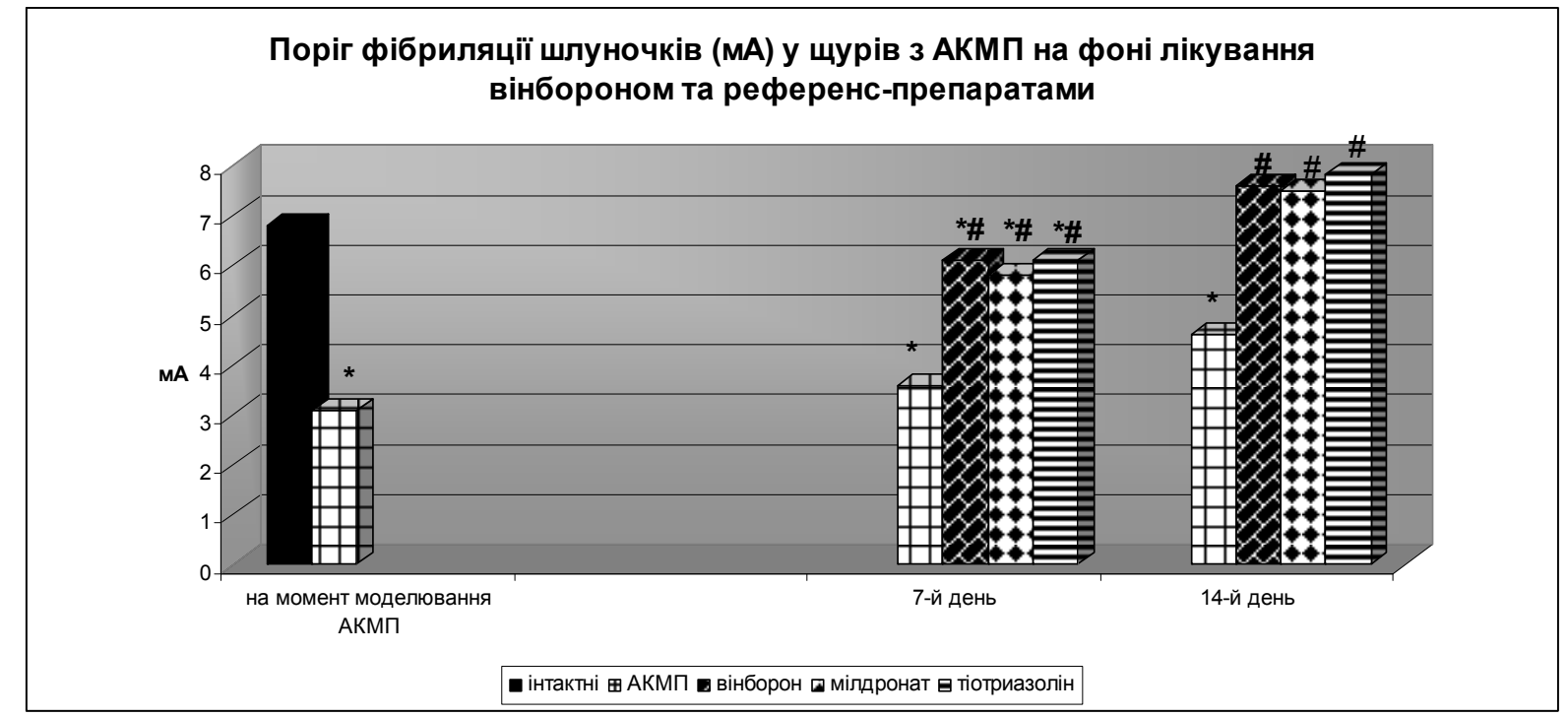

Рис. 1. Зміни електричної стабільності міокарда у щурів з АКМП і на тлі лікування

Примітка. 1.* - p<0,05 відносно інтактних щурів; \# - p<0,05 відносно щурів без лікування; АКМП - алкогольна кардіоміопатія

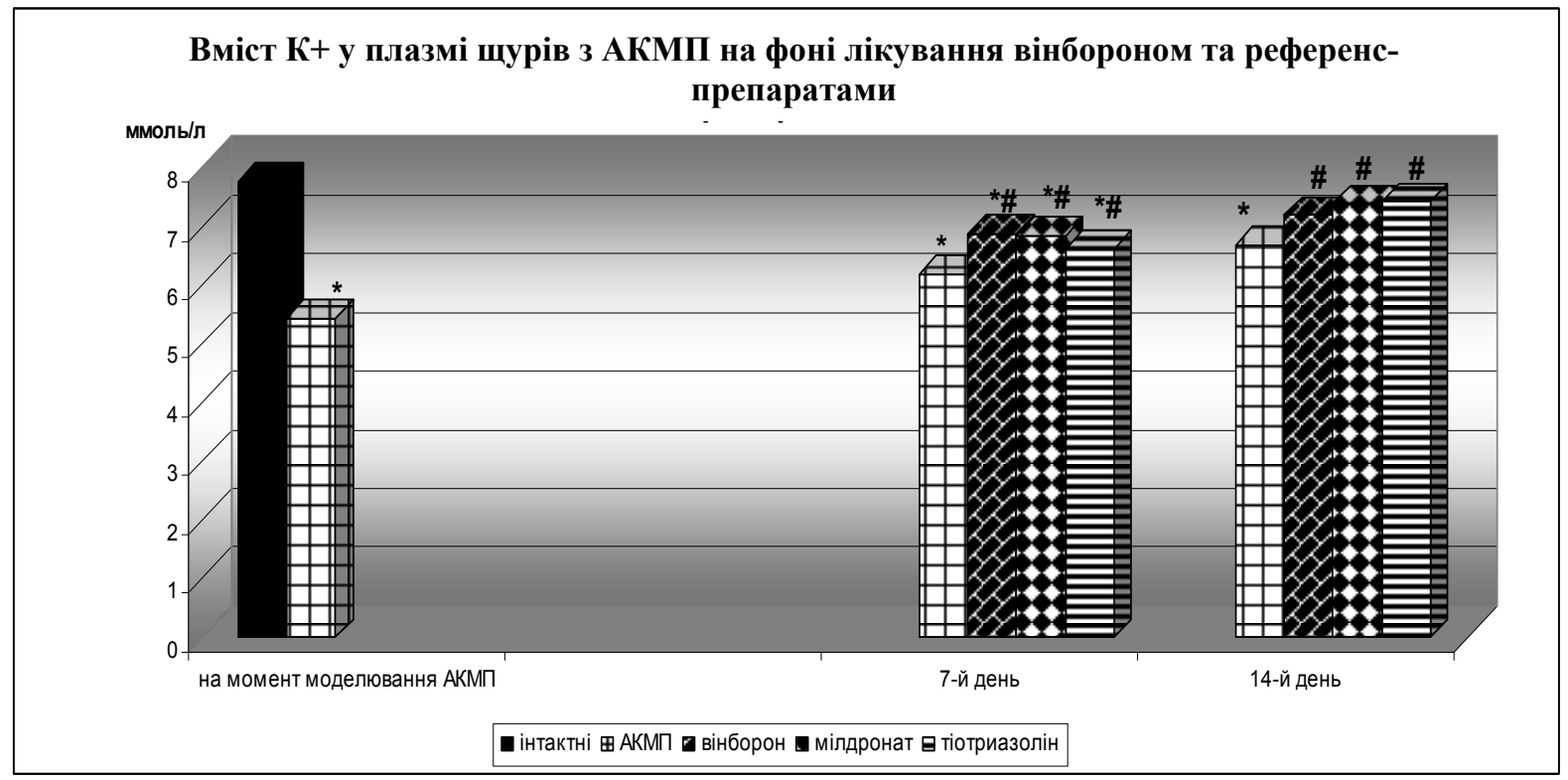

Рис. 2.А. Вміст іонів калію у щурів з АКМП і на тлі лікування

Примітка. 1.* - p<0,05 відносно інтактних щурів; 2. \# - p<0,05 відносно щурів без лікування; АКМП - алкогольна кардіоміопатія 


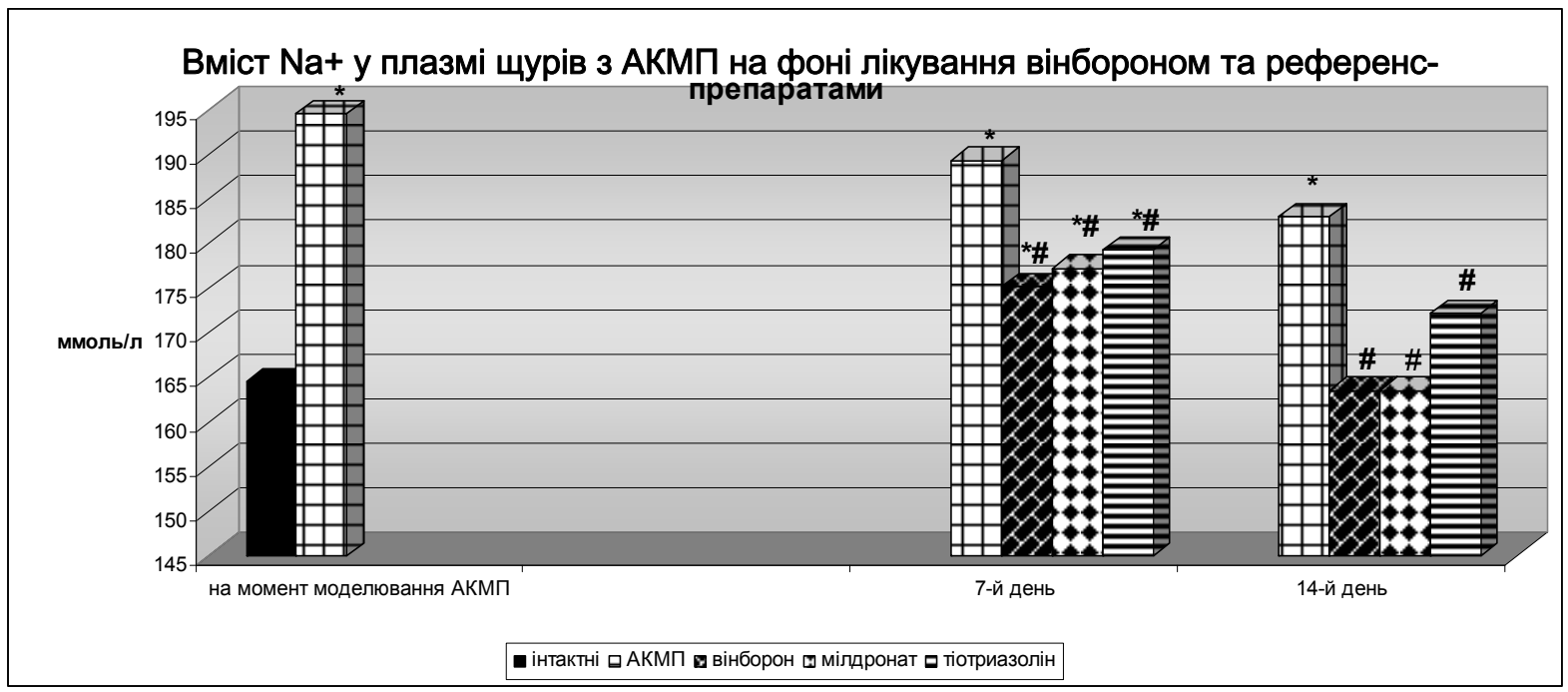

Рис. 2.Б. Вміст іонів натрію у щурів з АКМП і на тлі лікування

Примітка. 1.* - p<0,05 відносно інтактних щурів; 2. \# - p<0,05 відносно щурів без лікування; АКМП - алкогольна кардіоміопатія

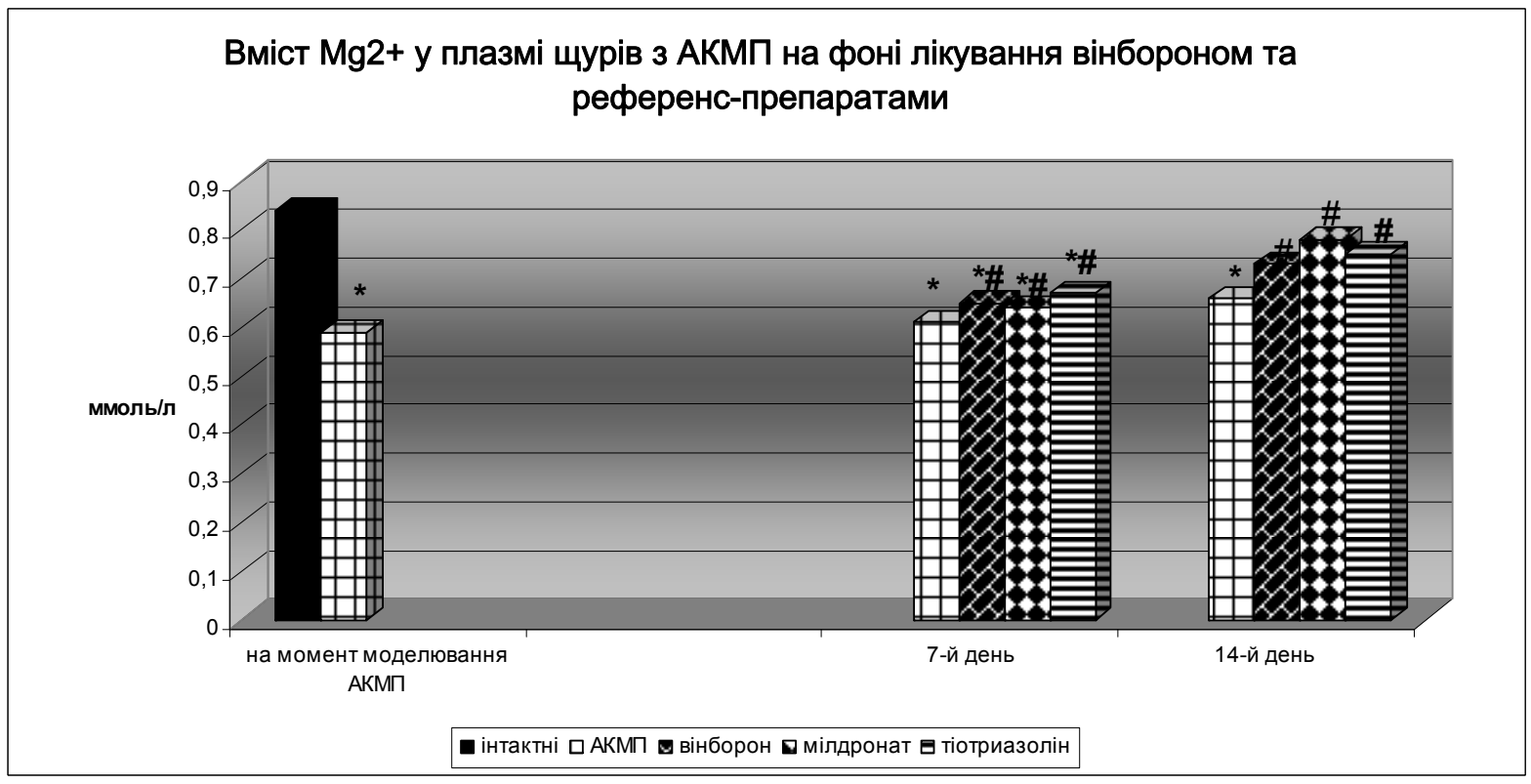

Рис. 2.В. Вміст іонів магнію у щурів з АКМП і на тлі лікування

Примітка. $1 .^{*}$ - p $<0,05$ відносно інтактних щурів; 2. \# - p<0,05 відносно щурів без лікування; АКМП - алкогольна кардіоміопатія

Біохімічні та біофізичні дослідження впливу етанолу на клітини різних органів дозволили ряду авторів прийти до висновку, що етанол, перш за все, пошкоджує сарколему, сприяючи підвищенню проникливості мембран, що призводить до порушення іонного балансу в клітинах, у тому числі і в кардіоміоцитах. У подальшому це веде до порушення злагодженості процесів збудження i скорочення, відбиваючись на біоелектричній активності міокарда [5].

За цих умов терапія вінбороном, так само як i референс-препаратами, сприяє відновленню електричної стабільності ураженого міокарда, підтвердженням чого є позитивна динаміка показника порогу фібриляції та нормалізація показників електролітного балансу. За величиною кардіопротекторної дії вінборон практично не поступа- вся тіотріазоліну та мілдронату. Крім того, виявлений нами фармакорегулювальний ефект вінборону можна також пов'язати з його мультимодальними фармакологічними властивостями: антиоксидантною, протиішемічною, антиагрегантною, антигіпоксичною, протифібриляторною, здатністю стимулювати репаративні процеси тощо [3].

\section{Висновок}

Проведені дослідження показали, що вінборон володіє достатньо виразною кардіопротекторною дією при алкогольній кардіоміопатії.

Перспективи подальших досліджень. Вінборон робить перспективним подальші дослідження цього засобу як препарату вибору при лікуванні даного патологічного стану. 


\section{Література}

1. Амосова Е.М. Метаболическая терапия повреждений миокарда, обусловленных ишемией: новый подход к лечению ИБС и сердечной недостаточности / Е.M. Амосова // Серия: “В помощь практическому врачу”. - Вып. 2. К: Б.и., 2000. - 10c.

2. Артемчук А. Ф. Клинические особенности и терапия сердечно-сосудистых нарушений при алкоголизме / А. Ф. Артемчук // Укр. кардіол. ж. -2000 . - № 4. - С. 68-71.

3. Вінборон - лікарський засіб 3 політропними фармакологічними властивостями / Г.І. Степанюк, І.Л. Черешнюк, Н.Г. Степанюк [та ін.] // Вісн. Вінн. держ. мед. ун-ту. - 2002. - Т. 6, № 1. - C. 111-114.

4. Єрохін Ю.А. Ураження серця при хронічній алкогольній інтоксикації / Ю.А. Єрохін, Д.Ф. Хрітін // 2012. Електронний ресурс. Режим доступа: http://www.mednet.com/publikac

5. Капустин А.В. Значение изменений миокарда для судебно-медицинской диагностики смерти от алкогольной кардиомиопатии / А.В. Капустин // Суд.-мед. экспертиза. - 2004. № 6. - С. 22-25.

6. Коваленко В.Н. Некоронарогенные болезни сердца / В.Н. Коваленко, Е.Г. Несукай. - К.: МОРИОН, 2001. - 480 с.
7. Раптова смерть при алкогольній кардіоміопатії / А.І. Найда, В.М. Нартіков, Л.П. Ногач [та ін.] // Практ. мед. - 2002. - № 3. - С. 66-70.

8. Рябенко Д.В. Алкогольная кардиомиопатия / Д.В. Рябенко, Т.М. Корниенко // Укр. кардіол. ж. -2010 . - № 4. - С. 94-97.

9. Тиотриазолин: фармакологические аспекты и клиническое применение / [Мазур И.А., Волошин Н.А., Чекман И.С. и др.]. - Запорожье, 2005. $-146 \mathrm{c}$.

10. Эффективная терапия алкогольной кардиомиопатии в эксперименте / А.В. Лычакова, М.К. Шевчук, Т.Н. Саватеева [и др.] // VIII Рос. нац. конгресс "Человек и лекарство". M., 2001. - C. 587.

11. Cardiomyopathy: An Overview / R. Wexler, T. Elton, A. Pleister [et al.] // Am. Fam. Physician. - 2009. - Vol. 79, № 9. - P. 778-784.

12. Men T. Russian mortality trends for 1991-2001: analysis by cause and region / T. Men // BMJ. 2003. - Vol. 327. - P. 960-964

13. Preedy V.R. Alcoholic muscle disease: features and mechanisms / V.R. Preedy, J.R. Salisbury, T.J. Peters // J. Pathol. - 1994. - Vol. 173. P. 309-315.

\section{ВЛИЯНИЕ ВИНБОРОНА НА ЭЛЕКТРИЧЕСКУЮ СТАБИЛЬНОСТЬ И ЭЛЕКТРОЛИТНЫЙ БАЛАНС МИОКАРДА ПРИ АЛКОГОЛЬНОЙ КАРДИОМИОПАТИИ У КРЫС}

\section{О.С. Пашинская}

Резюме. В эксперименте на крысах с алкогольной кардиомиоптией установлено, что винборон (5 мг/кг), так же как милдронат (50 мг/кг) и тиотриазолин (100мг/кг), обладает кардиопротекторным действием. Это проявляется нормализацией порога фибрилляции желудочков и уровня ионов $\mathrm{K}^{+}, \mathrm{Na}^{+} \mathrm{i} \mathrm{Mg}^{2+}$ в плазме крови. По величине данного эффекта винборон не уступает препаратам сравнения.

Ключевые слова: винборон, алкогольная кардиомиопатия, милдронат, тиотриазолин.

\section{INFLUENCE OF VINBORON ON THE ELECTRICAL STABILITY AND ELECTROLYTE BALANCE OF THE MYOCARDIUM IN CASE OF EXPERIMENTAL ALCOHOL CARDIOMYOPATHY IN RATS}

\section{O.S. Pashyns'ka}

Abstract. In experiments on rats with experimental alcohol cardiomyopathy it has been determined that vinboron ( $5 \mathrm{mg}$ per $\mathrm{kg}$ ), as well as mildronate (50 mg per $\mathrm{kg}$ ) and thiotriasoline (100 $\mathrm{mg}$ per $\mathrm{kg}$ ) exerts a cardioprotective action. It is manifested by a normalization of the heart ventricular fibrillation threshold and the blood level content of $\mathrm{Na}^{+}, \mathrm{K}^{+}, \mathrm{Mg}^{2+}$ ions. Vinboron does not yield to drugs of comparison as far as value of this particular effect is concerned.

Key words: vinboron, mildronat, thiotriasolinum, alcohol cardiomyopathy.

M.I. Pyrohov National Medical University (Vinnytsia)

Рецензент - проф. І.І. Заморський

Buk. Med. Herald. - 2013. - Vol. 17, № 1 (65). - P. 85-89

Надійшла до редакції 19.12.2012 року

(C) О.С. Пашинська, 2013 